\title{
Determination of Financial Rotation of Acacia nilotica (L.) Plantations: A Case Study in Faridpur District of Bangladesh
}

\author{
Jime Roy* $\quad$ Md. Melon Sujon Chandra Sarker Dr. Hasina Mariam Rukshana Akther \\ Forest Economics Division, Bangladesh Forest Research Institute, Chattogram-4211, Bangladesh
}

\begin{abstract}
Knowing the rotation age of farming trees is important to urge maximum return from it. Acacia nilotica (Babla) may be a widely planted farming tree especially in modern agroforestry practice mainly in northern, north western and south western region of Bangladesh. Farmers have little idea about optimum age of the trees to be cut. So, they fail to realize maximum enjoy it. No study has been undertaken to work out the optimum rotation age for A. nilotica in Bangladesh. during this study, an effort has been taken to unravel this problem. Plantations done by Bangladesh Forest Department (BFD) in Faridpur district has taken into consideration as study area. Total cost and total benefit for every plantation site was identified first. Then, Present Value of Benefit (PVB), Present Value of Cost (PVC) and Net Present Value of Benefit (NPVB) were determined to live the Land Expectation Value (Le), Internal Rate of Return (IRR) and Benefit-Cost Ratio (B/C). Using those parameters during this study, it's found that 11 to 14 years old plantations provided highest benefit to the farmers and this could be the acceptable rotation age for Babla trees in Faridpur district.
\end{abstract}

Keywords: Babla, Financial rotation, Forest Management, Faridpur, Bangladesh.

DOI: $10.7176 / \mathrm{JESD} / 12-4-05$

Publication date: February $28^{\text {th }} 2021$

\section{Introduction}

The arboriculture isn't only ecologically but also economically viable in modern agroforestry practice. Generally, Acacia species are exploited extensively under short rotation intensive culture to satisfy industrial requirements and generate ample employment (Chauhan \& Chauhan, 2011). To deal with the continual population pressure and increasing demands for timber and fuel wood, Acacia species was also introduced to Bangladesh in 19771978 (Hossain, 2015; Das \& Alam 2001). There are numerous Acacia farming trees during this country. Acacia nilotica (L.) (family: Mimosaceae) is one among them. Bargali and Bargali (2009) described the tree as a multipurpose nitrogen fixing tree legume widespread in Africa and Asia, and occurs also in Australia. it's commonly referred to as Babla, Indian gum acacia Tree, Kikar, Prickly Acacia, The Babul Tree (Hossain, 2015). It generally flowers and fruits within three to four years after germination. It flowers between June and September, and pods form between July and December and reach fully size by February-March; ripen from April-June. it's a deciduous tree species and most leaves fall between June and November. (Bargali \& Bargali, 2009, Gupta 1993, Hossian, 2015). it's one among the simplest fast growing agroforestry tree species which may grow in dry areas with biotic and abiotic stresses (Saqibet et al., 2019) having an excellent effect in soil amelioration (Bargali \& Bargali, 2009) by increasing remarkably the quantity of mineral nitrogen and total nitrogen within the superficial soil (Matinkhahet et al. 2015). This tree is additionally useful in production of tennis and gums $(250 \mathrm{~g} /$ tree $)$, timber $(500 \mathrm{~kg} /$ tree $)$, fuel $(260 \mathrm{~kg} /$ tree $)$, fodder $(25 \mathrm{~kg} /$ tree $)$ (Viswanathet et al., 2000) and different fertilizers as it's pods and other organs are very rich in $\mathrm{Na}, \mathrm{Ca}, \mathrm{P}, \mathrm{K}, \mathrm{Fe}, \mathrm{Zn}$ and $\mathrm{Mg}$ (Madboulyet et al., 2014). Not only that, Arora and Chaudhury (2017) showed, this species contributes largely in mitigation of global climate change with its high soil carbon pool $(111.71 \mathrm{Mg} / \mathrm{ha})$ and having an excellent amount of vegetation carbon stock $(43.35 \mathrm{Mg} / \mathrm{ha})$ when planted alongside Dalbergiasissoo. The tree may be a good host for Lac insect (Das \& Alam, 2001) and therefore the root may be a potential inhibitor of mosaic virus (TMV) (Hossain, 2015).

Normally, farm trees (like A. nilotica) are cut when farmers need money. Usually, they are doing not maintain the optimum age to fell the trees. They even don't know that various tree rotations impact broadly the income they receive. Ayyazet et al. (2014) stated that the economic returns are differently suffering from the various rotations of tree. In Indian subcontinent, plantations are managed on a 15-20 years' rotation for fuel wood and timber (Javaid \& Akhter, 2006).

Viswanathet et al. (2000) mentioned the rotation age of A. nilotica is 10 to 12 years and Hossain (2015) noted it 15 to 20 years. But Ayyazet et al. (2014) got different information from their investigation. They suggested 6 years (in two successive rotation of three years) as optimum age of the tree to be cut for getting maximum economic benefit. But they also added that the fertility of soil, availability of irrigation water and place of planting affect significantly in determining the particular rotation age additionally to other factors. for instance, Madboulyet et al. (2014) showed, the concentrations of the weather within the pods of A. nilotica are strongly suffering from the characteristics of the soil. Saqibet et al., (2019) also revealed a big correlation between seedling development and therefore the different amounts of biological fertilization. Its seedlings grow 
rapidly near water but more slowly in open grasslands. 95\% seeds become dead after two years but some seeds can germinate even after 15 years of drop. When seeds are disturbed by fire or by browsing the gastrointestinal system of animals, it helps more to germinate (Bargali \& Bargali, 2009). As its germination, growth etc. differ for various ecological, environmental, climatic and manual factors, the economically viable rotation age can vary from country to country.

In Bangladesh, A. niloticais cultivated and naturalized in northern districts and along the coastal areas (Das \& Alam, 2001). it's also scattered within the homesteads, graveyards, roadsides, crop field bonds and within the crop fields of southern and north-western parts of Bangladesh (Islam \& Kar, 1995; Hossain, 2015).

The south western region of Bangladesh is understood as mangrove forest region, positioning at $22^{\circ} 55^{\prime} \mathrm{N}$ latitude and $89^{\circ} 15^{\prime} \mathrm{E}$ longitudes having a good range of ecosystem (Rahman et al., 2016). A. nilotica can grow on degraded saline and alkaline soils having PH up to 9 and can also tolerate in both drought and flooded conditions for several months (Kayastha 1985; Hossain, 2015). Considering such quite reasons, A. nilotica plantations are raised largely in south western zone i.e. Barishal, Bagherhat, Faridpur, Noakhali, Bhola, Patuakhaliand Chattogram districts by Bangladesh Forest Department (BFD) and NGOs. The plantations are raised within the alongside of embankments and roads briefly and future rotations from 1976. In this study, only the plantations of Faridpur district done by Social Forest Division (SFD) has taken into consideration. The planters are wont to face the issues in determining the harvesting age, the particular timber volume also as prices of standing trees of their plantations. So, the study has been taken to work out the financial rotation by doing financial and economic analysis to make sure optimum profitable management of these plantations in Faridpur district.

\section{Methodology}

\subsection{Data Collection}

The needed data was collected in April, 2015 from A. nilotica plantations raised within 1991-92 to 2008-09 in Faridpur. Data collection and analysis were performed separately from administrative Forest Division of BFD named Social Forest Division. The plantation sites were identified with the assistance of the local forest staff. 15 sites were selected named Sadar, Nagarkanda, Laskardiya, Chagolnaiya, Kashiyan, Maksudpur, Duaripara, Ghatroad, Bhajonvanga, Gojariya, Shivarampur, Chandripur, Gazirtek, Gopalgonj and Bhatiyapara.The sites of the survey have the plantations established by SFD in Faridpur district. Age of these plantations were from 23 to six years. The age of plantations was confirmed by consulting the plantation journals kept within the respective Forest Range Offices.

Data collectors found plantations of various ages at an equivalent location. For this, it had been needed to mapped out the plantations on the idea of ages or plantation year with the locations. The chart given below is showing the code name of the sites which can help the reader of this paper to know the results from Result and Discussion section. it's also mentioned that Planting year and age of the plantations also will be used rather than code names of the sites.

\begin{tabular}{|c|c|c|c|}
\hline $\begin{array}{c}\text { Planting } \\
\text { year }\end{array}$ & $\begin{array}{c}\text { Age of the } \\
\text { plantation at 2015 }\end{array}$ & Locations & $\begin{array}{c}\text { Code Name of } \\
\text { the sites }\end{array}$ \\
\hline $1991-92$ & 23 & Sadar, Kashiyan, Gopalgonj Chandripur & $\mathrm{A}$ \\
\hline $1992-93$ & 22 & Nagarkanda, Laskardiya, Kashiyan & $\mathrm{B}$ \\
\hline $1993-94$ & 21 & Chagolnaiya, Shivarampur, Gazirtek & $\mathrm{C}$ \\
\hline $1996-97$ & 18 & Gojariya, Ghatroad, Bhajonvanga & $\mathrm{E}$ \\
\hline $2000-01$ & 14 & Bhatiyapara, Nagarkanda, Maksudpur & $\mathrm{F}$ \\
\hline $2003-04$ & 11 & Duaripara, Nagarkanda, Chandripur & $\mathrm{G}$ \\
\hline $2004-05$ & 10 & Sadar, Laskardiya, Maksudpur, Kashiyan & $\mathrm{I}$ \\
\hline $2006-07$ & 8 & Gazirtek, Gopalgonj, Bhajonvanga, Sadar & $\mathrm{J}$ \\
\hline $2007-08$ & 7 & Sadar, Nagarkanda, Laskardiya, Chagolnaiya, Kashiyan & \\
\hline $2008-09$ & 6 & Bhajonvanga, Gojariya, Maksudpur, Duaripara, & Bhatiyapara \\
\hline
\end{tabular}

A sampling design was prepared for selected forest division. Samples of 10 plots ( 0.01 ha of every plot) from each plantation year were considered for required data collection from selected sites. Height and Girth at Breast Height $(\mathrm{GBH})$ of the stands were measured from each selected plot using Haga Altimeter and Measuring tape respectively.

Information regarding financial aspects (direct cost) of $A$. nilotica plantation was collected from each location of Faridpur. Indirect costs including administration cost weren't taken under consideration. Data on the prices of plantation and other maintenance operations were collected from plantation journal of the local range office. the actual harvesting and processing costs were deducted in certain percentage (35\%) from standing value of the tree. The mode of selling and market value of round log and fuel wood of $A$. nilotica were collected from the closest local market of the study areas. Existing market value was considered to guage the input costs and 
returns of the species.

2.2 Analysis method

To find out the economic rotation and economics of Babla tree plantation the following formulae were used in the analyses:

Equation 01 :

IRR is the rate at which

$\sum \frac{\mathrm{R}_{\mathrm{n}}}{(1+\mathrm{i})}-\sum \frac{C_{n}}{(1+i) n}=0$

Equation 02 :

$\mathrm{NPV}$ (Net Present Value) $=\sum \frac{\mathrm{R} \mathrm{n}}{(1+\mathrm{i}) \mathrm{n}}-\sum \frac{C n}{(1+i)^{n}}$

Equation 03 :

$\mathrm{B} / \mathrm{C}$ Ratio $=\frac{\sum \frac{\mathrm{R} \mathrm{n}}{(1+\mathrm{i}) \mathrm{n}}}{\sum \frac{C_{n}}{(1+i) n}}$

Where,

IRR = Internal Rate of Return

$\mathrm{B} / \mathrm{C}=$ Benefit Cost ratio

$\mathrm{R}_{\mathrm{n}}=$ Benefits at every $\mathrm{n}$ year

$\mathrm{C}_{\mathrm{n}}=$ Costs at every $\mathrm{n}$ year

$\mathrm{n}=$ Number of years

$\mathrm{i}=$ Interest rate

Equation 04 :

$\mathrm{Le}=\frac{\mathrm{Yr}+\mathrm{T}_{\mathrm{b}}(1+\mathrm{i}) \mathrm{r}-\mathrm{b}+I\left[\frac{(1+i)^{r}-1}{i}\right]-C c(1+i) r-c-e\left[\frac{(1+i)^{r}-1}{i}\right]}{(1+i)^{r}-1}$

(Gunter,1984)

Where,

\begin{tabular}{|l|l|l|l|}
\hline Le & $=$ Land expectation value & C & $=$ net value of intermediate cost items \\
\hline $\mathrm{Y}$ & $=$ net yield at rotation age & $\mathrm{c}$ & $=$ age at which cost is incurred \\
\hline $\mathrm{T}$ & $=$ net value of intermediate cuttings & $\mathrm{e}$ & $=$ annual expenses \\
\hline $\mathrm{b}$ & $=$ age at which revenue is received & $\mathrm{r}$ & $=$ rotation \\
\hline$I$ & $=$ annual income & $\mathrm{i}$ & $=$ interest rate \\
\hline
\end{tabular}

Equation 05:

Equation for estimating volume under bark (Vub):

$\log (\mathrm{Vub})=-12.5189939+1.980535 * \log (\mathrm{D})+1.0775148 * \log (\mathrm{H}) \quad($ Latif, 1995)

Where,

Vub = Volume under bark $(\mathrm{m} 3) \quad \mathrm{D} \quad=$ Diameter $(\mathrm{cm}) \quad \mathrm{H} \quad=$ Total Height $(\mathrm{m})$

Equation 06:

$\mathrm{E}_{\mathrm{r}}=I_{\mathrm{s}}-\left(P_{s}+T_{t}+N_{d}\right)$

Where,

$\begin{array}{llll}\mathrm{E}_{\mathrm{r}} & \text { = elimination rate in percentage } & P_{s} & =\text { present stock } \\ I_{\mathrm{S}} & =\text { initial planted seedling } & T_{t} & =\text { number of trees thined } \\ N_{d} & =\text { number of trees that have naturally disappeared } & \end{array}$

Assumptions:

01 . Interest rate $10 \%$

04. Conversion factor $1 \mathrm{~m} 3=7 \mathrm{md}$

02. Cost of harvesting $10 \%$ of the total value

05. $1 \mathrm{mile}=1.609 \mathrm{~km}=0.892 \mathrm{acres}=0.35692$ hectares

03. Cost of processing $5 \%$ of the total value 


\section{Results and Discussion:}

Data was collected from 15 different locations of Faridpur district. Those plots were fixed after discussion with Divisional Forest Officer (DFO) of Faridpur Social Forest Division (SFD). Plantations were raised several times during a location. For that, we found different aged plantations in one location. All locations were in low salinity areas and, all plantations were in roadside and were mixed in nature. FD planted seedlings grown from $20 \mathrm{~kg}$ of Babla seeds per hectare. 10 plots were taken from every location which covers 0.1 ha. Every plot was 0.01 ha in size. Though the spacing alleged to be found $4 \mathrm{~m} 2$ but not found equally altogether places. That's why, it became difficult to seek out the amount of existing Babla trees which made data collectors count total existing trees per hectare manually. In analysis, Alternative Rate of Return (ARR) was counted $10 \%$.

Table 01. Basic Information of Babla Plantation in Faridpur

\begin{tabular}{|c|c|c|c|c|}
\hline Code of the Sites & Plantation Year & Age (Year) & Existing Babla (Number/ha) & Elimination Rate (\%) \\
\hline A & $1991-92$ & 23 & 412 & 32 \\
\hline B & $1992-93$ & 22 & 564 & 36 \\
\hline C & $1993-94$ & 21 & 398 & 58 \\
\hline D & $1996-97$ & 18 & 547 & 33 \\
\hline E & $2000-01$ & 14 & 815 & 21 \\
\hline F & $2003-04$ & 11 & 883 & 31 \\
\hline G & $2004-05$ & 10 & 427 & 79 \\
\hline H & $2006-07$ & 8 & 189 & 69 \\
\hline I & $2007-08$ & 7 & 306 & 62 \\
\hline J & $2008-09$ & 6 & 497 & 20 \\
\hline
\end{tabular}

Existing number of Babla trees per hectare found highest in Location F (883 nos.) and second highest in E ( 815 nos.). The elimination rates varied from $20 \%$ to $79 \%$, rock bottom elimination rate was found $20 \%$ in $\mathrm{F}$ and quite 50\% elimination rate were found in C, H, I and J area for the plantation year 1992-93, 2006-07, 2007-08 and 2008-09. the very best elimination rate was found in location $\mathrm{H}(79 \%)$. This happened could also be for lacking of awareness of local people about the plantations as they were grazing their cattle within the study areas indiscriminately, illegal cutting or felling and detachment of FD about the plantations after planting the seedlings.

Table 02. Growth information of Babla in the plantations of Faridpur.

\begin{tabular}{|c|c|c|c|c|c|c|c|c|c|}
\hline Location & \multirow{11}{*}{ 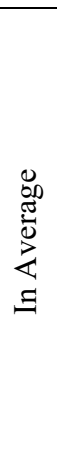 } & $\begin{array}{l}\mathrm{GBH} \\
\text { (Inch) }\end{array}$ & $\begin{array}{l}\text { Height } \\
\text { (m) }\end{array}$ & $\begin{array}{l}\mathrm{GBH} \\
(\mathrm{cm})\end{array}$ & $\log (\mathrm{V})$ & $\begin{array}{c}\mathrm{Vub} \\
\left(\mathrm{m}^{3} / \text { tree }\right)\end{array}$ & $\begin{array}{l}\text { Yield } \\
\left(\mathrm{m}^{3} / \mathrm{ha}\right)\end{array}$ & $\begin{array}{l}\text { Age } \\
\text { (Year) }\end{array}$ & $\begin{array}{c}\text { MAI } \\
\left(\mathrm{m}^{3} / \mathrm{ha}\right)\end{array}$ \\
\hline A & & 25.667 & 8.667 & 65.193 & -1.691 & 0.191 & 78.70 & 23 & 3.42 \\
\hline B & & 30.702 & 9.546 & 77.982 & -1.283 & 0.314 & 177.14 & 22 & 8.05 \\
\hline $\mathrm{C}$ & & 30.856 & 10.589 & 78.373 & -1.148 & 0.346 & 137.81 & 21 & 6.56 \\
\hline D & & 25.483 & 9.133 & 64.728 & -1.709 & 0.216 & 117.94 & 18 & 6.55 \\
\hline$E$ & & 25.349 & 9.696 & 64.387 & -1.646 & 0.229 & 186.72 & 14 & 13.34 \\
\hline $\mathrm{F}$ & & 24.919 & 9.446 & 63.294 & -1.758 & 0.223 & 196.74 & 11 & 17.89 \\
\hline $\mathrm{G}$ & & 22.613 & 7.885 & 57.437 & -2.094 & 0.146 & 62.26 & 10 & 6.23 \\
\hline $\mathrm{H}$ & & 21.961 & 10.053 & 55.781 & -1.889 & 0.180 & 33.94 & 08 & 4.24 \\
\hline I & & 20.076 & 9.207 & 50.994 & -2.200 & 0.146 & 44.76 & 07 & 6.39 \\
\hline $\mathrm{J}$ & & 11.778 & 6.833 & 29.916 & -3.477 & 0.038 & 18.67 & 06 & 3.11 \\
\hline
\end{tabular}

$\mathrm{Vub}=$ Volume under bark; GBH $=$ Girth at Breast Height

Table 02 shows the typical DBH (inch and $\mathrm{cm}$ ), height $(\mathrm{m})$, volume yield per hectare and MAI (Mean Annual Increment) for each studied location. the very best average height $(10.59 \mathrm{~m})$ and DBH $(78.37 \mathrm{~cm})$ were found within the site $\mathrm{C}$ for the plantation age 21 but rock bottom average height $(6.83 \mathrm{~m})$ and DBH (29.92) was found needless to say within the site $\mathrm{J}$ for the age 06 years.

Per tree volume under bark ( Vub) was calculated highest in location $\mathrm{C}(0.3463 \mathrm{~m} 3)$ but just in case of total yield per hectare, it had been found highest in location F (196.74m3) which drive MAI to be maximum (17.89 $\mathrm{m} 3 /$ ha) within the same location. Noticeably, the DBH, height and volume was found highest at the age of 21 but it's not asuitable period for a brief rotation species. Because MAI become lower with the time, elimination rate increases and management cost become higher.

From the given basic information and growth information (Table 01 and 02) of Babla plantations it had been observed that 11-year-old plantations was providing the very best number of survival trees, maximum yield and uppermost MAI.

All plantations were mixed in nature and about $50 \%$ of total trees were Babla (Acacia nilotica). The plantation aged up to six years was considered just for fuel wood and quite 6 years for both fuel wood and round $\log$. Nearly $50 \%$ of the entire yield was fuel wood in average. Market survey was conducted within the year 
2015. the typical market prices of fuel wood and round log were found Tk. 2667 per ton and Tk. 7438 per m3, respectively.

Table 03. Gross return received from Babla plantations of Faridpur till 2015.

\begin{tabular}{|c|c|c|c|c|c|c|c|c|c|}
\hline $\begin{array}{c}\text { Plantation } \\
\text { Year }\end{array}$ & $\begin{array}{c}\text { Plantation } \\
\text { Age }\end{array}$ & $\begin{array}{c}\text { Fuel } \\
\text { wood } \\
\text { (ton/ha) }\end{array}$ & $\begin{array}{c}\text { MAI of } \\
\text { Fuel } \\
\text { wood }\end{array}$ & $\begin{array}{c}\text { Fuel wood } \\
\text { Price } \\
(\mathrm{Tk} / \text { ton })\end{array}$ & $\begin{array}{c}\text { Round } \\
\text { log } \\
(\mathrm{m} 3 / \mathrm{ha})\end{array}$ & $\begin{array}{c}\text { Round Log } \\
\text { Price } \\
\left(\mathrm{Tk} / \mathrm{m}^{3}\right)\end{array}$ & $\begin{array}{c}\text { MAI of } \\
\text { Round } \\
\text { Log }\end{array}$ & $\begin{array}{c}\% \text { of } \\
\text { Total } \\
\text { Yield }\end{array}$ & $\begin{array}{c}\text { Gross } \\
\text { Return }\end{array}$ \\
\hline $1991-92$ & 23 & 37.33 & 1.62 & 99555.56 & 41.33 & 307416.67 & 1.80 & 52.52 & 406972.22 \\
\hline $1992-93$ & 22 & 84.00 & 3.82 & 224000.00 & 93.00 & 691687.50 & 4.23 & 52.50 & 915687.50 \\
\hline $1993-94$ & 21 & 65.33 & 3.11 & 174222.22 & 72.33 & 537979.17 & 3.44 & 52.49 & 712201.39 \\
\hline $1996-97$ & 18 & 56.00 & 3.11 & 149333.33 & 62.00 & 461125.00 & 3.44 & 52.57 & 610458.33 \\
\hline $2000-01$ & 14 & 88.67 & 6.33 & 236444.44 & 98.17 & 730114.58 & 7.01 & 52.58 & 966559.03 \\
\hline $2003-04$ & 11 & 93.33 & 8.48 & 248888.89 & 103.33 & 768541.67 & 9.39 & 52.52 & 1017430.56 \\
\hline $2004-05$ & 10 & 55.00 & 5.50 & 146666.67 & 6.60 & 49087.50 & 0.66 & 10.60 & 195754.17 \\
\hline $2006-07$ & 8 & 30.00 & 3.75 & 80000.00 & 3.60 & 26775.00 & 0.45 & 10.61 & 106775.00 \\
\hline $2007-08$ & 7 & 40.00 & 5.71 & 106666.67 & 4.80 & 35700.00 & 0.69 & 10.72 & 142366.67 \\
\hline $2008-09$ & 6 & 18.70 & 3.12 & 49866.67 & 0 & 0.00 & 0.00 & 0.00 & 49866.67 \\
\hline
\end{tabular}

Table 03 represented MAI of both fuel-wood and round log. In both case, the maximumincrement was found at the age of 11 and second maximum was found at the age 14 of Babla. Same result was observed just in case of return per hectare. Maximum return found from round log which worth Tk. 7,68,541.67 at the age of 11 and second highest from 14 . Higher (52.52\% and 52.58\% respectively) amount of yield received from round log.

It was found that the very best MAI for total yield $(17.89 \mathrm{~m} 3 / \mathrm{ha})$ at the age 11 year and second highest $(13.34 \mathrm{~m} 3 / \mathrm{ha})$ at the age 14 years within the sites $\mathrm{F}$ and $\mathrm{E}$ respectively (Table 02$)$. For fuel wood it had been 8.48 ton/ha and $6.33 \mathrm{ton} / \mathrm{ha}$ respectively. In other hand, the MAI of round $\log$ it had been $9.39 \mathrm{~m} 3 / \mathrm{ha}$ and seven .01 $\mathrm{m} 3$ /ha for 11-year old and 14-year old plantations respectively (Table 03).

Thus, after consideration of Table 01, 02 and 03; the rotation period for A. nilotica for Faridpur are often suggested and it's 11 to 14 -year old Babla considering both quite yield i.e. fuel wood and round $\log$.

But to succeed in during a final judgment about the rotation period of Babla in Faridpur, only basic, growth, and yield information aren't enough. it's also mandatory to try to to financial and economic analysis to work out the accuracy of the suggested rotation period.

As the dendro-ecological conditions vary at different locations the entire cost, net return, NPV, B/C ratio, IRR and Le of these plantations are calculated at different aged plantations of Faridpur District.

Table 04. Financial information of Babla plantation at different location/Ages in Faridpur.

\begin{tabular}{|c|c|c|c|c|c|c|c|c|}
\hline Age & $\begin{array}{c}\text { Seed } \\
\text { cost } \\
(\mathrm{Tk} / \mathrm{ha})\end{array}$ & $\begin{array}{c}\text { Manage- } \\
\text { ment cost } \\
(\mathrm{Tk} / \mathrm{ha})\end{array}$ & $\begin{array}{c}\text { Weeding } \\
\text { cost } \\
(\mathrm{Tk} / \mathrm{ha})\end{array}$ & $\begin{array}{c}\text { Watcher } \\
\text { cost } \\
(\mathrm{Tk} / \mathrm{ha})\end{array}$ & $\begin{array}{c}\text { Processing } \\
\text { cost } \\
(\mathrm{Tk} / \mathrm{ha})\end{array}$ & $\begin{array}{c}\text { Total Cost } \\
(\mathrm{Tk} / \mathrm{ha})\end{array}$ & $\begin{array}{c}\text { Gross } \\
\text { Return } \\
(\mathrm{Tk} / \mathrm{ha})\end{array}$ & $\begin{array}{c}\text { Net Return } \\
(\mathrm{Tk} / \mathrm{ha})\end{array}$ \\
\hline 23 & 240.00 & 5000.00 & 1500.00 & 15000.00 & 144840.28 & 166580.28 & 414972.22 & 248391.94 \\
\hline 22 & 240.00 & 5150.00 & 1545.00 & 30000.00 & 322890.63 & 359825.63 & 923687.50 & 563861.88 \\
\hline 21 & 240.00 & 5304.50 & 1591.35 & 30000.00 & 251670.49 & 288806.34 & 720201.39 & 431395.05 \\
\hline 18 & 240.00 & 5463.64 & 1639.09 & 30000.00 & 216060.42 & 253403.14 & 618458.33 & 365055.19 \\
\hline 14 & 240.00 & 5627.54 & 1688.26 & 30000.00 & 340695.66 & 378251.47 & 974559.03 & 596307.56 \\
\hline 11 & 240.00 & 5796.37 & 1738.91 & 30000.00 & 358500.69 & 396275.98 & 1025430.56 & 629154.58 \\
\hline 10 & 240.00 & 5970.26 & 1791.08 & 30000.00 & 70913.96 & 108915.30 & 203754.17 & 94838.87 \\
\hline 8 & 240.00 & 6149.37 & 1844.81 & 30000.00 & 39771.25 & 78005.43 & 114775.00 & 36769.57 \\
\hline 7 & 240.00 & 6333.85 & 1900.16 & 30000.00 & 47083.33 & 85557.34 & 135666.67 & 50109.33 \\
\hline 6 & 240.00 & 6523.87 & 1957.16 & 30000.00 & 18893.33 & 57614.36 & 54666.67 & -2947.69 \\
\hline
\end{tabular}

For financial analysis, different sorts of cost including seed, management, watcher, processing etc. are taken into consideration. Every cost decided on the average basis. during this study, Gross return was calculated from the earns of fuel wood and round log shown within the table 04. This investigation revealed that 11-year old plantations got highest net return which is Tk. 6,29,154.58 and therefore the second highest found within the 14year old plantation (Tk. 5,96,307.56). 6-year old plantation has negative net return because the total cost was higher where the income from those low aged trees was less. This financial analysis supports the previous finding from the prior analysis of Babla. Till now 11-year to 14-year aged Babla found more profitable than that of the opposite aged Babla plantations in Faridpur district. Now another investigation is often done by economic analysis of these plantations. 
Table 05. Economic information of Babla plantations in Faridpur District.

\begin{tabular}{|c|c|c|c|c|c|c|}
\hline Age & PVC & PVB & NPVB & \multirow{2}{*}{ IRR } & \multirow{2}{*}{ B-C ratio } & Le \\
\hline (Year) & (Tk/ha) & (Tk/ha) & (Tk/ha) & & & (Tk/ha) \\
\hline 23 & 67178 & 107811 & 40633 & $15 \%$ & 1.60 & 5108 \\
\hline 22 & 66990 & 106778 & 39788 & $15 \%$ & 1.59 & 5572 \\
\hline 21 & 61999 & 92007 & 30008 & $14 \%$ & 1.48 & 4689 \\
\hline 18 & 66496 & 104331 & 37835 & $16 \%$ & 1.57 & 8297 \\
\hline 14 & 112736 & 235902 & 123167 & $25 \%$ & 2.09 & 44027 \\
\hline 11 & 145411 & 328701 & 183290 & $34 \%$ & 2.26 & 98909 \\
\hline 10 & 56161 & 73126 & 16966 & $16 \%$ & 1.30 & 10645 \\
\hline 8 & 48203 & 49799 & 1595 & $11 \%$ & 1.03 & 1395 \\
\hline 7 & 53413 & 64073 & 10660 & $16 \%$ & 1.20 & 11237 \\
\hline 6 & 41202 & 28299 & -12903 & $-2 \%$ & 0.69 & -16723 \\
\hline
\end{tabular}

The NPV was found negative for six years old plantation shown in table 05. the very best NPVB (Tk. 183290/ha), IRR (34\%), B-C ratio (2.26), Le (Tk. 98909/ha) were found within the 11-year-old plantations and therefore the second highest NPVB, IRR, B-C ratio, IRR, Le were found within the 14-year-old plantations. from these criteria, it is often referred that economic rotation could also be fixed at 11 to 14 years old Babla trees for getting more enjoy both fuel wood and round log. to urge minimum return, farmer should wait a minimum of 7 years after planting Babla in Faridpur.

\section{Conclusion}

In this study, only Faridpur was considered as a representative district of south-western region of Bangladesh. So, further research is required to be done to urge more concrete result to repair the acceptable rotation age of Babla. Considering basic information, growth performance, yield calculation, financial and economic parameters for the A. nilotica plantations in selected locations, age period for financial rotation within 11 th to $14^{\text {th }}$ years were found optimum which is extremely much on the brink of the rotation age Viswanathet et al. (2000), Javaid \& Akhter (2006) and Hossain (2015) mentioned in their individual studies. So, harvesting of A. nilotica (Babla) trees within this era are going to be most profitable in Faridpur district of Bangladesh.

\section{Acknowledgement}

The authors are grateful acknowledged to Md. Abu Taher Hossain, Research Officer, Bangladesh Forest Research Institute, Chattogram, for his valuable comments on this manuscript.

\section{References}

Arora, P. \& Chaudhury, S. (2017), "Vegetation and Soil Carbon Pools of Mixed Plantation of Acacia nilotica and Dalbergia sissoo under Social Forestry Scheme in Kurukshetra, India." Journal of Materials and Environmental Sciences 8 (12), 4565-4572.

Asif, M., Saqib, H.M.U., Ahmad, I., Rashid, M.H.U., Farooq, T.H., Asif, M., Kashif, M., Iqbal, A. \& Nawaz, M.F. (2019), "Effect of Compost Application on the Growth of Acacia nilotica." Cercetari Agronomice in Moldova. 52, 66-73.

Ayyaz, F., Anjum, K., I. Qadir, Nouman, W., Afzal, S., \& Asif, M. (2014), "Best economic rotation of farm trees in Tehsil Muzaffargarh.” Journal of Agricultural Research 52(4), 569-579.

Bargali, K. \& Bargali, S. (2009), “Acacia nilotica: A multipurpose leguminous plant.” Nature and Science 7(4), 11-19.

Chauhan, S.K. \& Chauhan, R. (2011), "Short Rotation Forestry Species for Economic and Environmental Benefits: Country Report, (India)." IUFRO Symposium on "Short Rotation Forestry: Synergies for Wood Production and Environmental Amelioration" (February 10 12, 2011) PAU, Ludhianan (India).

Das, D.K. \& Alam, M.K. (2001), “Trees of Bangladesh.” Chittagong: Bangladesh Forest Research Institute.

Gunter, J.E. \& Haney, H.L. (1984), "Essentials of Forestry Investment Analysis. Instruction Manual." (ISBN 0882460773. Library of Congress Catalog 83-063342)

Gupta, R.K. (1993), "Multipurpose trees for agroforestry and wasteland utilization.”- 562.

Hossain, M.K. (2015), "Silviculture of Plantation Trees of Bangladesh." Arannayk Foundation, Dhaka, Bangladesh-361

Islam, M.S. \& Kar, N.K. (1995), "Contribution of Acacia nilotica (Linn.) Willd. Ex. Del. to the farming systems of Godabari Thana in the high Barind tract of Bangladesh.” Bangladesh Journal of Forest Science 24(2), 62-63.

Kayastha, B.P. (1985), "Sivics of the Trees of Nepal.” Kathmundu, Nepal. 177 pp.

Latif, M.A., Rahman, M.F. \& Das, S. (1995), "Volume Tables of Accia auricoliformis, Cassia siamia and Pinus 
Caribaea in Bangladesh.” Bangladesh Journal of Forest Science, 24 (2), 22-30.

Madbouly, M., Salih, M.E., Ali, E.A. \& Kamel, L.T. (2014), "Determination and Assessment of Essential Elements in Acacia Nilotica-a Medicinal and Folk uses by Different Analytical Methods." Journal of Advances in Chemistry, 10, 2283-2289.

Matinkhah, S., Shahbazi, A. \& Naiminia, M. (2016), "The Effects of Acacia nilotica and Prosopis juliflora as the Nitrogen Provider Trees on the Understory Soil of Them." Water and Soil Science, 25(1-4), 211-222.

Rahaman, M., Aminuzzaman, F.M., Hossain, M.B., Rashid, S.N. \& Rumainul, M.I. (2016), "Biodiversity, Distribution and Morphological Characterization of Mushrooms in the South Western Region of Banglades." International Journal of Advanced Research, 4, 60-79.

Viswanath, S., Nair, P.K.R., Kaushik, P.K. \& Prakasam, U. (2000), "Acacia nilotica trees in rice fields: A traditional agroforestry system in central India." Agroforestry Systems, 50, 157-177. 